\title{
CESSIE DALAM TINJAUAN HUKUM ISLAM
}

\author{
Devid Frastiawan Amir Sup \\ Universitas Darussalam (UNIDA) Gontor \\ devidfrastiawan@unida.gontor.ac.id
}

\begin{abstract}
Cessie is the submission of accounts receivable in the name regulated in Article 613 of the Civil Code. Cessie in principle is the sale and purchase of receivables, but in its development the cessie can also be used as collateral for debt. In Islamic law, detailed discussion of cessie has not yet existed, but in general the issue of accounts payable has been discussed in the hawalah contract. In the DSN-MUI fatwas cessies are categorized as active subjective innovations or forms of subrogation accompanied by compensation. On the other hand, conceptually, cessie, subrogation and innovation are different. From this description, this research will discuss about cessie in Islamic law review with hawalah approach. The research method used is qualitative-descriptive-literature. The conclusion obtained from this study. (1) Cessie requirements according to the Civil Code have not fulfilled the entire requirements for the formation of the contract contained in hawalah. (2) Cessie in the sale and purchase of receivables is included in hawalah haqq. (3) Cessie as debt collateral is included in hawalah haqq based on kafalah (guarantee). In the case of retro cessie, Hanafi scholars allow while Shafi'i scholars do not allow.
\end{abstract}

Keywords: cessie, Islamic law, hawalah

Abstrak: Cessie adalah penyerahan piutang atas nama yang diatur dalam Pasal 613 KUH Perdata. Cessie pada prinsipnya adalah jual beli piutang, namun dalam perkembangannya cessie juga dapat dipakai sebagai jaminan utang. Di dalam hukum Islam, pembahasan terperinci tentang cessie belum ada, tetapi secara umum perihal utang piutang telah dibahas pada akad hawalah. Dalam fatwa-fatwa DSN-MUI 
cessie dikategorikan sebagai novasi subjektif aktif atau bentuk subrogasi yang disertai dengan kompensasi. Di sisi lain, secara konseptual antara cessie, subrogasi, dan novasi adalah berbeda. Dari uraian tersebut, maka penelitian ini akan membahas tentang cessie dalam tinjauan hukum Islam dengan pendekatan hawalah. Metode penelitian yang digunakan bersifat kualitatif-deskriptif-kepustakaan. Kesimpulan yang didapat dari penelitian ini. (1) Syarat-syarat cessie menurut KUH Perdata belum memenuhi keseluruhan syarat pembentukan akad yang terkandung di dalam hawalah. (2) Cessie dalam jual beli piutang termasuk dalam hawalah haqq. (3) Cessie sebagai jaminan utang termasuk dalam hawalah haqq yang didasarkan pada kafalah (penjaminan). Dalam hal retro cessie, ulama Hanafi membolehkan sedangkan ulama Syafi'i tidak membolehkan.

Keywords: cessie, hukum Islam, hawalah.

\section{PENDAHULUAN}

Pengalihan hak atas suatu piutang dapat terjadi karena cessie, subrogasi, atau novasi (Usman 2009). Cessie adalah suatu perbuatan hukum mengalihkan piutang, yaitu penyerahan piutang atas nama yang dilakukan dengan cara membuatkan akta otentik atau akta di bawah tangan, kemudian dilakukan pemberitahuan mengenai adanya penyerahan tersebut kepada debitur (Sakkirang 2011), dan pengalihan ini harus disetujui oleh debitur (Winarno and Ismaya 2006).

Piutang-piutang atas nama yang dapat dialihkan kepada kreditur baru, yaitu hak penjual atas harga yang dialihkan, hak kreditur atas piutang yang dialihkan, dan juga hak tagihan atas ganti rugi (Sutarno 2014). Cessie pada prinsipnya adalah jual beli piutang (Supramono 2009), karena secara umum piutang dapat dialihkan kepada pihak ketiga (Widjaja and Sapardan 2006). Dalam perkembangannya, cessie juga dapat digunakan sebagai jaminan utang (Sakkirang 2011).

Terdapat dua hal yang terkait dengan pengalihan piutang tersebut. Pertama, penjualan putus (assets sales without recourse). Dalam penjualan 
piutang jenis ini, penjual piutang tidak lagi memiliki kewajiban untuk membeli kembali piutang yang tidak tertagih oleh pembeli. Pada umumnya transaksi ini dilakukan dalam anjak piutang murni. Melalui proses penjualan (yang dilakukan secara on-ballance sheet ini), resiko yang dihadapi oleh penjual atas piutang yang dijual tersebut dialihkan kepada pembeli. Penjualan pada umumnya dilakukan dengan diskonto. Diskonto ini menggambarkan dua hal, yaitu harga pengembalian oleh debitur piutang di masa akan datang (nilai masa depan yang dihitung pada saat piutang dijual = current value of the debt) dan nilai persentase piutang yang diperkirakan tidak dapat dipenuhi oleh debitur piutang tersebut (jika piutang yang dijual bersumber dari berbagai debitur). Kedua, penjualan tidak putus (assets sales with recourse). Penjualan tidak putus adalah penjualan aset dengan janji atau kewajiban untuk membeli kembali dalam jangka waktu tertentu. Pada umumnya penjualan tidak putus ini dilakukan untuk melakukan pembiayaan sementara karena pada prinsipnya piutang yang dijual tersebut tidak benar-benar dimaksudkan untuk dijual (dalam pengertian yang sebenarnya yaitu pengalihan hak milik atas piutang tersebut), melainkan hanya sebagai jaminan dalam rangka memperoleh pinjaman sementara (bisa juga dalam bentuk bridging finance) (Widjaja and Sapardan 2006).

Cessie, subrogasi, dan novasi merupakan produk hukum dari KUH Perdata yang pada hakikatnya memiliki kesamaan dengan hawalah di dalam hukum Islam. Hukum Islam adalah seperangkat peraturan berdasarkan wahyu Allah dan Sunnah Rasul tentang tingkah laku manusia mukallaf yang diakui dan diyakini berlaku dan mengikat untuk semua umat yang beragama Islam. Dari definisi tersebut dapat dipahami bahwa hukum Islam mencakup hukum syariah dan hukum fiqh, karena arti syara' dan fiqh terkandung di dalamnya (Mardani 2010).

Meskipun klausul cessie, subrogasi, dan novasi tidak disebutkan secara mendetail dalam hukum Islam, namun pembahasannya dapat dimasukkan ke dalam hawalah karena terkait dengan utang piutang. Hawalah adalah memindahkan sesuatu dari satu tempat ke tempat lain (Hakim 2011), yang dalam 
penelitian ini hawalah dimaknai sebagai pengalihan piutang. Dalam dunia komersial, pengalihan piutang dengan menggunakan hawalah melahirkan beberapa masalah. Pertama, akad hawalah dalam figh klasik termasuk kategori uqud tabarru', artinya akad tolong menolong di antara pelaku transaksi tanpa mengharapkan imbalan. Dengan kata lain, akad ini bersifat sosial, bukan komersial. Padahal di dalam dunia modern, di mana jasa merupakan komoditi yang harus dijual, maka hawalah tidak mungkin dilakukan tanpa biaya. Kedua, penerima pengambilalihan piutang itu (muhal 'alaih) meminta jasa untuk penagihan. Sebab untuk melakukan penagihan kepada pihak yang berhutang harus mengeluarkan biaya dan tenaga. Ketiga, jasa penagihan biasanya langsung dikurangkan dari nilai yang terdapat dalam surat piutang. Jika yang memindahkan kewajiban itu pihak yang berutang, maka jasa yang diminta adalah karena harus mencari dana tunai untuk menutupi kewajiban itu. Biaya jasa ditambahkan kepada jumlah hutang, yang perhitungannya bisa dalam bentuk nominal atau persentase. Keempat, dalam surat piutang, terkadang hutang yang ditanggung mengandung bunga, yang oleh para ulama dianggap sesuatu yang harus dihindari (Hakim 2012).

Selain berdasarkan KUH Perdata, ketentuan cessie, subrogasi, dan novasi di Indonesia juga terdapat dalam Fatwa DSN-MUI, yaitu Fatwa DSN-MUI No: 103/DSN-MUI/X/2016 tentang Novasi Subjektif Berdasarkan Prinsip Syariah dan Fatwa DSN-MUI No: 104/DSN-MUI/X/2016 tentang Subrogasi berdasarkan prinsip Syariah. Dalam kedua fatwa tersebut, cessie dikategorikan sebagai novasi subjektif aktif (penggantian da'in) dengan kompensasi ('iwadh) atau bentuk subrogasi yang disertai dengan kompensasi. Dalam dua fatwa tersebut belum ada uraian lengkap tentang cessie.

Secara konseptual, cessie, subrogasi, dan novasi adalah berbeda. Dalam cessie, utang piutang yang lama tidak dihapus, hanya beralih kepada pihak ketiga sebagai kreditur baru. Sedangkan dalam subrogasi, utang piutang yang lama dihapus, untuk kemudian dihidupkan lagi bagi kepentingan kreditur baru, dengan 
cara membayar kepada kreditur lama. Dalam hal novasi, utang piutang yang lama dihapus untuk diganti dengan utang piutang yang baru (pembaharuan utang piutang) (Suharnoko et al. 2005).

Berdasarkan uraian di atas, dapat diketahui bahwa cessie di dalam hukum Islam belum dibahas. Selain itu, walaupun dalam fatwa-fatwa DSN-MUI cessie dikategorikan sebagai novasi subjektif aktif (penggantian da'in) dengan kompensasi ('iwadh) atau bentuk subrogasi yang disertai dengan kompensasi, namun pembahasannya juga belum mencakup hal-hal lain yang mendetail terkait dengan cessie. Selanjutnya, secara konseptual pun antara cessie, subrogasi, dan novasi adalah berbeda. Oleh karena itu, penelitian ini akan membahas tentang cessie dalam tinjauan hukum Islam dengan pendekatan hawalah. Adapun pembahasannya nanti akan dirumuskan menjadi tiga sub bab masalah. (1) Bagaimana tinjauan hukum Islam terhadap syarat-syarat cessie? (2) Bagaimana tinjauan hukum Islam terhadap cessie dalam jual beli piutang? (3) Bagaimana tinjauan hukum Islam terhadap cessie sebagai jaminan utang?

\section{KERANGKA TEORI}

Hawalah secara bahasa berasal dari kata hawwala yang berarti ghayyara (mengubah) dan naqala (memindahkan). Terkadang diartikan sebagai shahadah (kesaksian) dan kafalah (jaminan). Hawalah adalah memindahkan sesuatu dari satu tempat ke tempat lain (Hakim 2011), yang dalam penelitian ini hawalah dimaknai sebagai akad pemindahan piutang suatu pihak kepada pihak lain (Arifin 2003).

Landasan hukum tentang hawalah. Pertama, ijma', para ulama sepakat atas kebolehan hawalah (Huda and Heykal 2010). Kedua, qiyas, menurut metodologi ushul figh, hawalah dapat dianalogikan dengan kafalah (Muhammad 2000). Ketiga, kaidah figh:

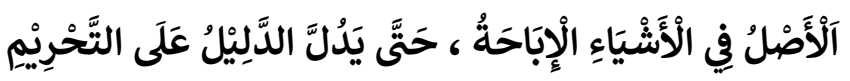




\section{"Segala sesuatu pada dasarnya boleh, kecuali bila ada dalil yang} mengharamkannya."

\section{آلضََّرَرُ يُزَالُ}

"Kemudharatan harus dihilangkan."

Rukun hawalah terdiri atas muhil (debitur), muhal (kreditur), muhal 'alaih (kreditur baru), muhal bihi (piutang), dan akad. Muhil, muhal, dan muhal 'alaih harus memiliki kecakapan hukum (PPHIMM 2009). Dalam artian mampu bertindak menurut hukum. Apabila belum mampu, harus dilakukan oleh walinya. Oleh sebab itu, suatu akad yang dilakukan oleh orang yang kurang waras (gila) atau anak kecil yang belum mukallaf, hukumnya tidak sah (Sahrani and Abdullah 2011).

Terdapat beberapa syarat dalam muhal bihi. Tsabit, yaitu adanya hak piutang (dain). Luzum atau ailun ila al-luzum (mendekati luzum), yaitu telah wujud, bersifat final, mengikat, dan tidak bisa dibatalkan meskipun belum terjamin dari gugur (ghair mustaqirr) atau dengan kata lain utang yang telah kehilangan hak opsi (khiyar) untuk dibatalkan. Boleh di-i'tiyadl atau di-istibdalkan, yaitu penukaran tanggungan (dain) yang bukan berstatus sebagai mutsman yang telah disepakati saat transaksi dengan barang lain. Ma'lum dan tasawi, yaitu bisa diterima dan serasi (TLP 2013).

Akad dilihat dari kedudukannya dibedakan menjadi akad yang pokok (al'aqd al-ashli) dan akad accessoir (al-'aqd at-tab'i) (Anwar 2010). Syarat pembentukan akad dibedakan menjadi syarat terjadinya akad, syarat sahnya akad, syarat pelaksanaan akad, dan syarat kepastian hukum (Nawawi 2012).

Syarat terjadinya akad ada dua macam. Pertama, syarat-syarat yang bersifat umum, yaitu syarat yang wajib sempurna wujudnya dalam berbagai akad. Pihak-pihak yang melakukan akad mampu bertindak menurut hukum (mukallaf). Obyek akad itu diketahui oleh syara'. Akad itu tidak dilarang oleh nas syara'. Akad yang dilakukan itu memenuhi syarat-syarat khusus dengan akad yang bersangkutan, di samping harus memenuhi syarat-syarat umum. Akad itu 
bermanfaat. ljab tetap utuh sampai terjadi kabul. Kedua, syarat-syarat yang bersifat khusus, yaitu syarat yang wujudnya wajib ada dalam sebagian akad. Syarat khusus ini bisa juga disebut idhafi (tambahan) yang harus ada di samping syaratsyarat yang umum (Sahrani and Abdullah 2011).

Syarat sahnya akad diantaranya adalah adanya kekhususan syarat akad pada setiap terjadinya akad, serta terhindarnya seseorang dari enam kecacatan, yaitu kebodohan, keterpaksaan, pembatasan waktu, perkiraan, ada unsur kemadharat-an, dan syarat-syarat akad yang rusak (fasid). Syarat pelaksanaan akad ada dua, yaitu pemilikan dan kekuasaan. Syarat kepastian hukum dalam pembentukan akad adalah kepastian. Jika tidak luzum maka akad batal atau dikembalikan (Nawawi 2012).

Selain itu ada beberapa prinsip dasar yang harus terpenuhi dalam pembuatan akad. Pertama, suka sama suka. Akad harus dibuat atas dasar ridha kedua belah pihak, oleh karena itu akad tidak diperbolehkan jika mengandung unsur paksaan dari salah satu pihak atau lebih. Kedua, tidak boleh menzalimi. Prinsip ini menegaskan adanya kesetaraan posisi sebelum terjadinya akad. Seseorang tidak boleh merasa dizalimi karena kedudukannya sehingga terpaksa melepaskan hak miliknya. Oleh karena itu kita dilarang melakukan akad dengan orang gila, anak-anak, atau mereka yang tidak tahu terhadap apa yang akan diperjanjikan. Ketiga, keterbukaan (transparansi). Prinsip ini menegaskan pentingnya pengetahuan yang sama antar pihak yang bertransaksi terhadap obyek kerja sama. Subyek perjanjian harus benar-benar terbebas dari adanya manipulasi (najsy) data atau kondisi. Seseorang dilarang menyembunyikan kekurangan barang dan melebihkan keunggulannya, sehingga seolah-olah barang itu tanpa cacat sedikit pun. Prinsip transparansi ini juga harus sampai pada persoalan risiko yang akan dihadapi kelak di kemudian hari. Keempat, penulisan. Prinsip ini menegaskan pentingnya dokumen yang ditandatangani dan disaksikan oleh para pihak yang melakukan perjanjian. Penulisan ini dimungkinkan juga terkait dengan variabel jangka waktu dalam suatu jenis transaksi (Anshori 2011). 
Konsep keuangan Islam didasarkan pada prinsip moralitas dan keadilan. Oleh karena itu harus selaras dan memenuhi prinsip syariah, yaitu antara lain transaksi yang dilakukan oleh para pihak harus bersifat adil, halal, thayyib, dan mashlahat. Selain itu, transaksi dalam keuangan Islam yang sesuai dengan syariah harus terbebas dari unsur-unsur larangan. (1) Riba, yaitu unsur bunga atau return yang diperoleh dari penggunaan uang untuk mendapatkan uang (money for money). (2) Maysir, yaitu unsur spekulasi, judi, dan sikap untung-untungan. (3) Gharar, yaitu unsur ketidakpastian yang antara lain terkait dengan penyerahan, kualitas, kuantitas, dan sebagainya (Sutedi 2009).

Secara umum, hawalah dapat dibedakan menjadi tiga, yaitu berdasarkan jenis pemindahannya, berdasarkan rukun hawalah-nya, dan berdasarkan ada tidaknya imbalan. Berdasarkan jenis pemindahannya, hawalah terdiri dari hawalah dayn (pemindahan utang) dan hawalah haqq (pemindahan piutang). Berdasarkan rukunnya, hawalah terdiri dari hawalah muthlaqah (bukan sebagai ganti dari pembayaran utang utang) dan hawalah muqayyadah (sebagai ganti dari pembayaran utang). Berdasarkan imbalannya (ujrah), hawalah terdiri dari hawalah bighairi ujrah dan hawalah bil ujrah (Djamil 2012).

\section{METODE}

Penelitian ini menggunakan metode kualitatif, lebih bersifat deskriptif, dengan jenis penelitian kepustakaan (library research). Peneliti melakukan studi pustaka terlebih dahulu dengan mencari buku-buku yang terkait dengan cessie dan hawalah pada perpustakaan-perpustakaan di wilayah Ponorogo. Setelah jumlah buku yang diperkirakan akan digunakan telah cukup, maka dirumuskanlah judul, permasalahan, serta kerangka penulisannya.

Berdasarkan metode dan jenis penelitian ini, maka dalam hal pengumpulan data menggunakan metode dokumentasi sehingga akan diperoleh suatu penjabaran yang mendetail. Peneliti mengumpulkan data dari buku-buku yang telah dikutip, menyusunnya dengan melakukan penyesuaian kata-kata yang 
kurang tepat, dan kemudian mendeskripsikannya dalam sub bab yang sesuai dengan kerangka penulisan yang telah ditentukan sebelumnya. Agar lebih proporsional dan representatif, data yang diperoleh diolah dengan metode editing dan pengorganisasian data.

Selanjutnya, proses analisis dilakukan dengan metode deduksi menggunakan pendekatan hawalah dan kemudian ditarik menjadi sebuah kesimpulan akhir yang diperoleh dari hasil proses analisis tersebut. Dalam penelitian ini, sistematika penulisan disesuaikan dengan Author Guideline Jurnal "Jurisprudensi: Jurnal IImu Syariah, Perundang-Undangan, dan Ekonomi Islam" Fakultas Syariah IAIN Langsa, Aceh.

\section{CESSIE MENURUT KUH PERDATA}

KUH Perdata (Kitab Undang-Undang Hukum Perdata) merupakan ketentuan hukum yang berasal dari produk pemerintah Hindia Belanda yang diundangkan pada tahun 1848. Masih berlaku di Indonesia sepanjang tidak bertentangan dengan UUD 1945, Pancasila, peraturan perundang-undangan, serta dibutuhkan (HS. 2005).

Penyerahan hak-hak piutang atas nama, khususnya untuk benda bergerak dilakukan dengan cessie (HS. 2005). Cessie diatur dalam buku II, Pasal 613 ayat (1) KUH Perdata, yang menyebutkan bahwa "penyerahan piutang-piutang atas nama dan barang-barang lain yang tidak bertubuh, dilakukan dengan jalan membuat akta otentik atau di bawah tangan yang melimpahkan hak-hak atas barangbarang itu kepada orang lain". Selanjutnya pada Pasal 613 ayat (2) KUH perdata menyebutkan bahwa "penyerahan ini tidak ada akibatnya bagi yang berutang sebelum penyerahan itu diberitahukan kepadanya atau disetujuinya secara tertulis atau diakuinya".

Piutang atas nama adalah piutang yang pembayarannya dilakukan kepada pihak yang namanya tertulis dalam surat piutang tersebut, dalam hal ini kreditur lama. Akan tetapi dengan adanya pemberitahuan tentang pengalihan piutang atas 
nama kepada debitur, maka debitur terikat untuk membayar kepada kreditur baru dan bukan kepada kreditur lama (Suharnoko et al. 2005). Terdapat perbedaan cessie dan subrogasi (Prakoso 1989; Hariri 2011):

\begin{tabular}{|c|c|c|c|}
\hline No & Perihal & Cessie & Subrogasi \\
\hline 1 & Akta. & $\begin{array}{l}\text { Wajib, baik akta otentik } \\
\text { atau di bawah tangan. }\end{array}$ & Tidak membutuhkan. \\
\hline 2 & Penggunaan. & $\begin{array}{l}\text { Dapat digunakan apabila } \\
\text { telah disahkan, yaitu telah } \\
\text { diberitahukan dan } \\
\text { disetujui oleh debitur. }\end{array}$ & $\begin{array}{l}\text { Tidak dibutuhkan } \\
\text { persetujuan debitur. }\end{array}$ \\
\hline 3 & Piutang. & $\begin{array}{l}\text { Dialihkan kepada kreditur } \\
\text { baru. }\end{array}$ & $\begin{array}{l}\text { Dibayar oleh kreditur } \\
\text { baru. }\end{array}$ \\
\hline 4 & $\begin{array}{l}\text { Penghapusan } \\
\text { utang. }\end{array}$ & $\begin{array}{l}\text { Setelah membayar kepada } \\
\text { kreditur baru. }\end{array}$ & $\begin{array}{l}\text { Dapat terhapus apabila } \\
\text { kreditur menyetujui untuk } \\
\text { dibayarkan oleh kreditur } \\
\text { baru. }\end{array}$ \\
\hline 5 & Terjadinya. & Dengan perjanjian. & $\begin{array}{l}\text { Dengan perjanjian atau } \\
\text { undang-undang. }\end{array}$ \\
\hline 6 & Peran debitur. & $\begin{array}{l}\text { Mutlak pasif, oleh } \\
\text { karenanya membutuhkan } \\
\text { pemberitahuan tentang } \\
\text { penggantian kreditur. }\end{array}$ & Pasif dan aktif. \\
\hline
\end{tabular}

Selanjutnya, juga terdapat perbedaan cessie dan novasi (Prodjodikoro 2000):

\begin{tabular}{|l|l|l|l|}
\hline No & Perihal & Cessie & Novasi \\
\hline
\end{tabular}


JURISPRUDENSI:

Jurnal IImu Syariah, Perundang-undangan dan Ekonomi Islam

Volume 11 Edisi 1 Tahun 2019, 44-73

Doi: https://doi.org/10.32505/jurisprudensi.v11i1.995

\begin{tabular}{|c|l|l|l|}
\hline 1 & Akta. & $\begin{array}{l}\text { Wajib, baik akta otentik } \\
\text { atau di bawah tangan. }\end{array}$ & $\begin{array}{l}\text { Tidak membutuhkan, } \\
\text { karena dapat terjadi } \\
\text { secara kesimpulan } \\
\text { (stilezwijgend). }\end{array}$ \\
\hline 2 & Peran debitur. & $\begin{array}{l}\text { Cukup kuatu } \\
\text { pemberitahuan kepada } \\
\text { debitur. }\end{array}$ & $\begin{array}{l}\text { Debitur terlibat dalam } \\
\text { penentuannya. }\end{array}$ \\
\hline 3 & $\begin{array}{l}\text { Hak-hak dan } \\
\text { hipotek dari } \\
\text { perjanjian. }\end{array}$ & $\begin{array}{l}\text { Berpindah kepada } \\
\text { kreditur baru. }\end{array}$ & Tidak tentu. \\
\hline
\end{tabular}

Cessie hampir mirip sifatnya dengan pand (gadai) piutang atas nama, di mana keduanya dilakukan dengan akta dan harus ada pemberitahuan. Perbedaannya, dalam cessie perbuatan hukum itu sudah selesai dengan dibuatnya akta tersebut. Pemberitahuan hanya dilakukan supaya debitur mengetahui dan kemudian terikat oleh adanya cessie itu. Sedang dalam gadai perbuatan hukum itu selesai setelah adanya pemberitahuan, dengan dibuatnya akta saja perbuatan hukum belum selesai. Perbedaan tersebut di atas penting artinya dalam hal adanya kepailitan (Sofwan 1981).

\section{TINJAUAN HUKUM TERHADAP SYARAT-SYARAT CESSIE}

Penyerahan (levering) adalah penyerahan suatu benda oleh pemilik atau atas namanya kepada orang lain, sehingga orang lain ini memperoleh hak milik atas benda itu (Sofwan 1981). KUH Perdata mengenal tiga macam barang (barang bergerak, barang tetap, dan piutang atas nama), maka juga dikenal tiga macam levering, penyerahan kekuasaan (bezit) untuk barang bergerak, balik nama untuk barang tetap, dan cessie untuk piutang atas nama (Subekti 2000).

Dalam cessie, Pasal 613 ayat (1) KUH Perdata mewajibkan untuk dibuatkan akta, baik otentik maupun di bawah tangan. Akta adalah tulisan yang memang 
sengaja dibuat untuk dijadikan bukti tentang suatu peristiwa dan ditandatangani (Suhardana 2009). Di dalam Pasal 1868 KUH Perdata "suatu akta otentik adalah suatu akta yang dibuat dalam bentuk yang ditentukan undang-undang oleh atau di hadapan pejabat umum yang berwenang untuk itu di tempat akta itu dibuat". Sedangkan menurut Pasal 1874 KUH Perdata "yang dianggap sebagai tulisan di bawah tangan adalah akta yang ditandatangani di bawah tangan, surat, daftar, surat urusan rumah tangga dan tulisan-tulisan lain yang dibuat tanpa perantaraan seorang pejabat umum". Di dalam Pasal 1875 KUH Perdata:

"Suatu tulisan di bawah tangan yang diakui kebenarannya oleh orang yang dihadapkan kepadanya atau secara hukum dianggap telah dibenarkan olehnya, menimbulkan bukti lengkap seperti suatu akta otentik bagi orang yang menandatanganinya, ahli warisnya serta orang-orang yang mendapat hak dari mereka. Ketentuan Pasal 1871 berlaku terhadap tulisan itu."

Selanjutnya, Pasal 1871 KUH Perdata:

"Akan tetapi suatu akta otentik tidak memberikan bukti yang sempurna tentang apa yang termuat di dalamnya sebagai penuturan belaka, kecuali bila yang dituturkan itu mempunyai hubungan langsung dengan pokok isi akta. Jika apa yang termuat dalam akta itu hanya merupakan suatu penuturan belaka yang tidak mempunyai hubungan langsung dengan pokok isi akta, maka hal itu hanya dapat digunakan sebagai permulaan pembuktian dengan tulisan."

Kebenaran suatu akta di bawah tangan adalah adanya tanda tangan. Apakah tanda tangan tersebut dapat diakui kebenarannya, didasarkan pada pihak yang mengakui memberikan atau yang membuat tanda tangan tersebut, baik dilakukan secara serta merta atau di bawah sumpah (Rahman and Rinaldy 2013).

Setelah dibuatnya akta tersebut maka harus diadakan pemberitahuan kepada debitur, sesuai dengan Pasal 613 ayat (2) KUH Perdata. Dalam hubungan ini kreditur yang memindahkan piutang tersebut disebut cedent. Kreditur yang baru itu disebut cessionaris. Sedang debitur dari piutang yang dipindahkan itu 
disebut cessus. Pemindahan piutang dengan cessie itu biasanya terjadi karena adanya jual beli (Sofwan 1981). Agar penyerahan tersebut mengikat bagi debitur, maka harus diberitahukan kepada debitur atau disetujui atau diakui secara tertulis oleh debitur (Miru 2016).

Untuk sahnya penyerahan itu harus memenuhi syarat-syarat tertentu. Pertama, harus ada perjanjian yang zakelijk, yaitu perjanjian yang menyebabkan pindahnya hak-hak kebendaan (zakelijke rechten). Dari perjanjian yang zakelijk ini tidak bisa timbul verbintenis, jadi berbeda sekali dengan perjanjian yang terdapat dalam buku III KUH Perdata. Perjanjian dalam buku III KUH Perdata umumnya bersifat obligatoir, yaitu perjanjian yang menimbulkan verbintenis. Jadi kesimpulannya, perjanjian obligatoir tidak menimbulkan atau menyebabkan pindahnya hak zakelijk melainkan hanya menimbulkan hak-hak persoonlijk (Sofwan 1981).

Kedua, harus ada titel (alas hak). Titel atau alas hak itu adalah hubungan hukum yang mengakibatkan penyerahan atau peralihan barang (Sofwan 1981). Di dalam Pasal 584 KUH Perdata:

"Hak milik atas suatu barang tidak dapat diperoleh selain dengan pengambilan untuk dimiliki, dengan perlekatan, dengan lewat waktu, dengan pewarisan, baik menurut undang-undang maupun menurut surat wasiat, dan dengan penunjukan atau penyerahan berdasarkan suatu peristiwa perdata untuk pemindahan hak milik, yang dilakukan oleh orang yang berhak untuk berbuat terhadap barang itu."

Tentang titel ini ada dua teori. Pertama, teori causal, menurut teori ini sahnya penyerahan tergantung pada alas hak, jika alas haknya sah maka penyerahannya sah dan sebaliknya. Jadi harus ada titel yang nyata. Kedua, teori abstrak, menurut teori ini penyerahan dan alas hak itu merupakan hal yang terpisah satu sama lain. Untuk sahnya penyerahan tidak tergantung pada alas hak yang nyata. Jadi bisa terjadi bahwa penyerahan itu akan sah juga sekalipun titelnya tidak sah tanpa titel sekalipun. Menurut Pasal 584 KUH Perdata penyerahan itu 
harus memenuhi adanya titel, tetapi bisa nyata atau titel anggapan. Oleh karena itu, baik ajaran causal maupun ajaran abstrak, untuk sahnya suatu penyerahan memerlukan adanya titel, hanya bedanya menurut ajaran causal titelnya harus nyata/riil sedangkan dalam ajaran abstrak titelnya cukup dengan titel anggapan saja (Natadimaja 2009). Di dalam Pasal 1313 KUH Perdata:

"Suatu persetujuan adalah suatu perbuatan di mana satu orang atau lebih mengikatkan diri terhadap satu orang lain atau lebih." Selanjutnya di dalam Pasal 1320 KUH Perdata, "Supaya terjadi persetujuan yang sah, perlu dipenuhi empat syarat: (1) Kesepakatan mereka yang mengikatkan dirinya; (2) Kecakapan untuk membuat suatu perikatan; (3) Suatu pokok persoalan tertentu; (4) Suatu sebab yang tidak terlarang."

(1) Ada kesepakatan bagi mereka yang mengikatkan dirinya (ada persetujuan kehendak antara pihak yang membuat perjanjian), artinya pihakpihak yang membuat perjanjian harus mempunyai kemauan secara sukarela atau bebas untuk mengikatkan dirinya dalam suatu perjanjian. Kemauan (kehendak) sukarela (bebas) merupakan syarat utama untuk sahnya suatu perjanjian. Perjanjian dapat dibatalkan apabila syarat kesepakatan (kemauan bebas/sukarela) tidak dipenuhi, misalnya terjadi karena paksaan (dwang), kekhilafan (dwaling), atau penipuan (bedrog). (2) Ada kecakapan untuk membuat perjanjian. Artinya kedua belah pihak harus cakap menurut hukum untuk bertindak sendiri (rechts-bekwaamheid atau capacity), misalnya dewasa, sehat akal pikiran, dan tidak dilarang oleh undang-undang untuk melakukan perbuatan hukum. Apabila syarat kecakapan tidak dipenuhi, maka perjanjian dapat dibatalkan. (3) Ada suatu hal tertentu, artinya barang yang menjadi obyek perjanjian harus ditentukan jenisnya. Apabila syarat suatu hal tertentu tidak dipenuhi, maka perjanjian batal demi hukum. (4) Ada suatu sebab yang halal (causa halal), artinya jika suatu perjanjian tidak ada sebab atau causa (oorzaa), maka perjanjian tidak mempunyai kekuatan hukum. Pengertian lain sebab atau causa yang halal adalah tidak boleh bertentangan dengan undang-undang, 
kesusilaan, dan ketertiban, atau kepentingan umum. Suatu perjanjian yang bertentangan dengan undang-undang, kesusilaan, atau ketertiban umum menjadi batal demi hukum (Sugiarto 2013).

Ketiga, Harus dilakukan oleh orang yang berwenang menguasai benda tersebut (Beschikkings Bevoegdheid). Syarat ini dapat dijumpai di dalam Pasal 584 KUH Perdata. Dan syarat ini tidak lain adalah pelaksanaan dari suatu azas hukum, Azas Nemoplus, yaitu bahwa seorang tidak dapat mengalihkan hak melebihi apa yang menjadi haknya. Dan lazimnya yang berwenang untuk menguasai benda itu adalah pemilik. Dikatakan lazimnya, sebab ada juga kemungkinan orang lain, yaitu seorang berpiutang yang mempunyai piutang-piutang yang masanya sudah dapat ditagih. Ketika kemudian debitur tidak membayar, maka orang yang berpiutang tersebut mempunyai hak untuk menyita sebagian dari barang-barang yang kemudian dijual untuk melunasi piutang-piutangnya (Sofwan 1981).

Keempat, harus ada penyerahan nyata. Penyerahan nyata (feitelijke levering) yaitu penyerahan dari tangan ke tangan. Feitelijke levering ini harus dibedakan dengan juridische levering. Dari perjanjian-perjanjian yang bersifat obligatoir itu timbul dua macam kewajiban penyerahan yaitu harus ada penyerahan nyata dan harus ada penyerahan yuridis. Dan ini biasanya hanya dicakup dengan satu kata saja yaitu levering (Sofwan 1981). Dalam bahasa Perancis ada dua macam istilah, yaitu traditio (juridische levering) dan deliverance (penyerahan nyata). Untuk benda bergerak, penyerahan nyata dan penyerahan yuridis bersamaan terjadinya. Untuk benda tak bergerak, antara penyerahan nyata dengan penyerahan yuridis tidak bersamaan (Natadimaja 2009).

Penyerahan hak-hak piutang atas nama, khususnya untuk benda bergerak dilakukan dengan cessie (HS. 2005). Pengalihan piutang tersebut di dalam Islam dikenal dengan hawalah. Dalam hubungan ini kreditur yang memindahkan piutang disebut cedent (muhal), kreditur yang baru disebut cessionaris (muhal 'alaih), dan debitur dari piutang disebut cessus (muhil). 
Cessie adalah suatu cara untuk menyerahkan hak milik atas piutang atas nama dan barang-barang lain yang tidak bertubuh, maka untuk sahnya penyerahan itu harus memenuhi syarat-syarat tertentu di dalam penyerahan.

Pertama, harus ada perjanjian yang zakelijk. Hak milik/kekuasaan termasuk di dalam syarat pelaksanaan akad dalam hukum Islam. Kekuasaan adalah kemampuan seseorang dalam ber-tasharruf, sesuai dengan ketetapan syariah, baik dengan ketetapan asli yang dilakukan oleh dirinya, maupun sebagai pengganti (mewakili seseorang). Dalam hal ini, disyaratkan antara lain barang yang dijadikan obyek akad itu harus miliknya orang yang berakad, jika diwakilkan tergantung dari izin pemiliknya yang asli, serta barang yang dijadikan obyek akad tidak berkaitan dengan pemilikan orang lain. Dengan adanya hak milik/kekuasaan, maka selain syarat pelaksanaan akad terpenuhi, syarat kepastian hukum juga terpenuhi. Karena dalam pembentukan suatu akad adalah kepastian (Nawawi 2012).

Kedua, harus ada titel (alas hak). Syarat-syarat sah perjanjian di dalam Pasal 1320 KUH Perdata jika ditinjau berdasarkan syarat-syarat terjadinya akad dalam hukum Islam adalah sebagai berikut:

1. ljab tetap utuh sampai terjadi kabul. Ketentuan Pasal 1320 ayat (1) KUH Perdata mensyaratkan adanya kesepakatan para pihak. ljab kabul merupakan suatu bentuk kesepakatan antara pihak-pihak yang mengikatkan dirinya di dalam hukum Islam. Kesepakatan merupakan jalan dari para pihak untuk mendapat manfaat dari kesepakatan tersebut, selain itu para pihak wajib memenuhi syarat-syarat khusus (selain syarat umum) dengan akad yang bersangkutan (Sahrani and Abdullah 2011). Karena suatu kesepakatan merupakan undang-undang bagi para pihak yang membuatnya.

2. Pihak-pihak yang melakukan akad mampu bertindak menurut hukum (mukallaf), apabila belum mampu, harus dilakukan oleh walinya (Sahrani and Abdullah 2011). Ketentuan Pasal 1320 ayat (2) KUH Perdata mensyaratkan kecakapan hukum para pihak. Hal ini dalam hukum Islam juga termasuk di 
dalam syarat sahnya akad, di antaranya adalah adanya kekhususan syarat akad pada setiap terjadinya akad, serta terhindarnya seseorang dari enam kecacatan, yaitu kebodohan, keterpaksaan, pembatasan waktu, perkiraan, ada unsur ke-madharat-an, dan syarat-syarat akad yang rusak (fasid) (Nawawi 2012).

3. Obyek akad itu diketahui oleh syara' (berbentuk harta, dimiliki seseorang, bernilai harta menurut syara', dan harus ada serta dapat diserahkan ketika berlangsung akad) (Sahrani and Abdullah 2011). Ketentuan pasal 1320 ayat (3) KUH Perdata mensyaratkan suatu obyek tertentu. Kriteria obyek ini di dalam KUH Perdata cakupannya sangat luas, dan sangat dimungkinkan kriteria obyek tersebut tidak sesuai dengan ketentuan syara'. Obyek akad berupa piutang/dain, di dalam hukum Islam disyaratkan tsabit, luzum atau ailun ila al-luzum, boleh di-i'tiyadl atau di-istibdal-kan, serta ma'lum dan tasawi (TLP 2013).

4. Akad itu tidak dilarang oleh nash syara' (Sahrani and Abdullah 2011). Ketentuan Pasal 1320 ayat (4) KUH Perdata mensyaratkan suatu sebab yang tidak terlarang menurut undang-undang, kesusilaan, dan ketertiban atau kepentingan umum, yang di dalam hukum Islam nilai-nilai dari hal-hal tersebut harus berjalan beriringan dengan ketentuan nash syara'. Dalam konsep keuangan Islam, suatu kesepakatan (transaksi) haruslah terbebas dari unsur larangan, yakni riba, maysir, dan gharar. Sedangkan menurut KUH Perdata, selama suatu kesepakatan telah memenuhi suatu syarat-syarat sah perjanjian, maka kesepakatan yang telah dibuat itu adalah sah dan merupakan undang-undang bagi para pihak yang membuatnya.

Ketiga, harus dilakukan oleh orang yang wenang menguasai benda tersebut (Beschikkings Bevoegdheid). Sama halnya dengan kekuasaan, pemilikan juga termasuk di dalam syarat pelaksanaan akad di dalam hukum Islam. Pemilikan adalah sesuatu yang dimiliki oleh seseorang, sehingga ia bebas dengan apa yang 
ia miliki sesuai dengan aturan syariah serta tidak berkaitan dengan pemilikan orang lain (Nawawi 2012).

Keempat, harus ada penyerahan nyata. Salah satu syarat obyek akad di dalam hukum Islam, yaitu harus ada dan dapat diserahkan ketika berlangsung akad (Sahrani and Abdullah 2011). Dengan adanya perjanjian dan penyerahan, maka hak milik terhadap suatu obyek akad telah berpindah.

\section{TINJAUAN HUKUM ISLAM TERHADAP CESSIE DALAM JUAL BELI PIUTANG}

Cessie dalam sudut pandang hukum perdata merupakan suatu bentuk penyerahan hak milik sebagaimana disyaratkan dalam Pasal 584 KUH Perdata yang mengikuti suatu peristiwa hukum yang bertujuan untuk mengalihkan hak milik atas suatu benda. Sebelum dilakukannya penyerahan (dalam bentuk cessie), hak milik atas benda (berupa piutang atas nama) belumlah beralih. Dengan demikian, cessie bukanlah suatu perbuatan hukum yang berdiri sendiri, melainkan cessie merupakan kelanjutan dari peristiwa hukum perdata yang dibuat dengan tujuan untuk mengalihkan hak milik atas piutang atas nama tersebut. KUH Perdata tidak secara tegas memberikan pengertian dari peristiwa perdata yang dimaksudkan, namun jika kita kembali kepada hakikat dari peristiwa perdata dalam hubungan penyerahan kebendaan, secara sederhana dapat dikatakan bahwa yang termasuk dalam peristiwa perdata tersebut merupakan perbuatan hukum berupa perjanjian yang dibuat oleh dua pihak dengan tujuan untuk mengalihkan hak milik atas kebendaan tertentu.

Dalam konteks yang sederhana, perjanjian yang berhubungan dengan tujuan pengalihan hak milik dapat kita temui dalam ketentuan jual beli yang diatur dalam Bab V Buku III KUH Perdata, tukar menukar yang diatur dalam Bab VI Buku III KUH Perdata, serta hibah yang diatur dalam Bab X Buku III KUH Perdata. Jika memperhatikan ketentuan sebagaimana diatur dalam ketiga jenis perjanjian tersebut, dari rumusan Pasal 1459 KUH Perdata (dalam jual beli), Pasal 1546 jo. 
Pasal 1459 KUH perdata (dalam tukar menukar), dan Pasal 1686 KUH Perdata (yang berlaku untuk hibah) menunjukkan dengan tegas bahwa sebelum dilakukannya penyerahan (dalam bentuk cessie), hak milik atas benda (berupa piutang atas nama) belumlah beralih (Widjaja and Sapardan 2006).

Dengan demikian, selain cessie, masih ada yang harus diperhatikan agar suatu piutang yang dialihkan tersebut dapat benar-benar beralih dalam hukum. Rumusan benar-benar beralih ini merupakan suatu rumusan yang perlu dan penting untuk diperhatikan. Piutang atas nama haruslah dikeluarkan dengan tujuan dan kontra prestasi memperoleh pembayaran atas piutang yang dialihkan tersebut. Dalam konteks yang demikian, berarti ada suatu bentuk jual beli, dalam hal kompensasi atau kontra prestasi yang diterima berbentuk uang tunai atau setara tunai. Agar seluruh piutang atas nama yang dijual oleh kreditur lama keluar dari kepemilikan kreditur lama dan tidak lagi mengikat kreditur lama dengan alasan apapun juga, maka jual beli harus dilakukan secara putus (tanpa hak regres/without recourse) (Widjaja and Sapardan 2006).

Dalam penjualan piutang jenis ini, penjual piutang tidak lagi memiliki kewajiban untuk membeli kembali piutang yang tidak tertagih oleh pembeli. Melalui proses penjualan, risiko yang dihadapi oleh penjual atas piutang yang dijual tersebut dialihkan kepada pembeli. Penjualan pada umumnya dilakukan dengan diskonto. Diskonto ini menggambarkan dua hal, yaitu harga pengembalian oleh debitur piutang di masa akan datang (nilai masa depan yang dihitung pada saat piutang dijual = current value of the debt) dan nilai persentase piutang yang diperkirakan tidak dapat dipenuhi oleh debitur piutang tersebut (jika piutang yang dijual bersumber dari berbagai debitur) (Widjaja and Sapardan 2006).

Cessie adalah suatu cara pengalihan piutang atas nama yang diatur dalam Pasal 613 KUH Perdata. Pengalihan ini terjadi atas dasar suatu peristiwa perdata, seperti perjanjian jual beli antara kreditur lama dengan calon kreditur baru (Suharnoko et al. 2005). Di dalam Islam, pengalihan piutang ini disebut hawalah haqq, yaitu pemindahan hak atau piutang atau tagihan (dayn) yang dimiliki 
seseorang atau satu pihak kepada orang atau pihak lain. Dayn merupakan lawan dari Ayn. Ayn adalah suatu obyek tertentu atau suatu harta yang nyata atau jelas keberadaannya (real asset). Dayn dipahami sebagai kewajiban seseorang untuk membayar sejumlah kewajiban dari transaksi yang obyeknya berupa dayn atau utang. Cakupan dayn ini pada awalnya dipahami sebagai kewajiban membayar dari suatu transaksi real, namun dalam perkembangannya yang dinilai sebagai dayn adalah sesuatu yang dianggap sama dengan utang, yaitu seperti surat berharga (Djamil 2012).

Di dalam hukum Islam, pertukaran surat berharga (termasuk di dalamnya juga piutang atas nama) sebagai sebuah transaksi jual beli pada dasarnya tidak diperbolehkan. Bagi surat berharga yang merupakan representasi dari barang atau jasa, sebagian ulama membolehkan untuk melakukan transaksi pertukaran (jual beli). Sedangkan surat berharga yang bukan merupakan representasi dari barang atau jasa, dilarang untuk melakukan pertukaran. Menurut mazhab Hanbali dan Zahiri, pertukaran surat berharga yang merupakan representasi dari barang atau jasa itu diperbolehkan selama penjualan tersebut dilakukan kepada yang berutang (bai' al-dayn lil madin - sale of debt to the debtor) dengan adanya kepastian untuk melakukan pembayaran (mustaqir/confirmed). Sedangkan apabila tidak ada kepastian melakukan pembayaran (non-confirmed/ghair mustaqir) maka pertukaran tersebut dilarang (Djamil 2012).

Di samping itu, ada beberapa pendapat para ulama yang berkenaan dengan melakukan pertukaran/penjualan surat berharga kepada pihak ketiga (bai'al-dayn lil ghairu madin - sale of debt to third party). Di antara pendapat tersebut adalah sebagai berikut:

1. Kebanyakan ulama mazhab Hanafi dan Syafi'i, serta beberapa ulama Hanbali dan Zahiri secara tegas tidak membolehkan hal ini. Ibn Taimiyah membolehkannya bila utangnya adalah utang yang pasti pembayarannya (confirmed/mustaqir) (Djamil 2012). 
2. Imam Siraji, Subki, dan Nawawi membolehkannya dengan tiga syarat: "three conditions laid down by Shiraji, Subki, Nawawi: (a) The dayn must be a spot dayn not muajjal. (b) The debtor is a rich man, and accept the selling, or there is strong evidence of dayn. (c) Pay the price on spot basis."

Sedangkan Imam Anas bin Malik dan Zurqoni membolehkannya dengan delapan syarat.

"Eight conditions laid down by Malik and Zurqoni: (a) Price on the spot. (b) Easily accessible the capacity to pay the debt. (c) Debt recognized by debtor. (d) Price must be from something else different from the debt self. (e) Should not be based on selling a gold with silver or opposite. (f) Should not be any enmity between the buyer and the debtor. (g) Should be an item that can be a subject of selling before possessing it. (h) Good intention." (Karim 2004).

Selanjutnya, dalam suatu penjualan putus, pada umumnya penjualan dilakukan dengan diskonto. Sebagian ulama yang tergabung dalam Dewan Syariah Malaysia berpendapat bahwa utang atau dain sama dengan harta benda (debt = property). Oleh karena itu, mengingat dain merupakan property, maka perlakuan kepada dain bisa dilakukan sebagaimana perlakuan kepada property, yaitu bisa dimiliki dan diperjualbelikan sesuai dengan harga pasar termasuk jual beli dengan harga diskon. Sebagian ulama lain, termasuk sebagian besar ulama di Indonesia yang tergabung dalam Dewan Syariah Nasional, memiliki pendapat tersendiri. Mereka umumnya berpendapat bahwa utang sama dengan uang (debt $=$ money). Mengingat utang/dain sama dengan uang/money, maka uang hanya boleh dipertukarkan dengan uang senilai uang tersebut (Djamil 2012). 


\section{TINJAUAN HUKUM ISLAM TERHADAP CESSIE SEBAGAI JAMINAN UTANG}

Pasal 1131 KUH Perdata, "segala barang-barang bergerak dan tak bergerak milik debitur, baik yang sudah ada maupun yang akan ada, menjadi jaminan untuk perikatan-perikatan perorangan debitur itu". Pada dasarnya istilah jaminan itu berasal dari kata "jamin" yang berarti "tanggung", sehingga jaminan dapat diartikan sebagai tanggungan (Saliman et al. 2008). Istilah jaminan merupakan terjemahan dari bahasa Belanda, yaitu zekerheid atau cautie yang mencakup secara umum cara-cara kreditur menjamin dipenuhinya tagihannya, di samping pertanggungjawaban umum debitur terhadap barang-barangnya (HS. 2016).

Jaminan utang adalah pemberian keyakinan kepada pihak kreditur (pihak yang berpiutang) atas pembayaran utang-utang yang telah diberikannya kepada debitur (pihak yang berutang), yang terjadi baik karena hukum maupun yang terbit dari suatu perjanjian yang bersifat accessoir (perjanjian ikutan) terhadap perjanjian pokoknya berupa perjanjian yang menerbitkan utang piutang baik berupa jaminan kebendaan maupun jaminan perorangan. Jika jaminan kebendaan dilakukan dengan atau tanpa penyerahan kekuasaan dan menikmati hasil dari barang objek jaminan tersebut, pada umumnya diberikan hak untuk dibayarkan utang terlebih dahulu kepada kreditur, dengan beberapa pengecualian, di mana pembayaran utangnya diambil dari hasil penjualan barang-barang jaminan utang tersebut (Fuady 2014). Tujuan jaminan adalah untuk melindungi kreditur dari risiko kerugian, baik yang disengaja maupun yang tidak disengaja. Lebih dari itu jaminan yang diserahkan oleh debitur merupakan beban, sehingga debitur akan bersungguh-sungguh untuk mengembalikan utang yang diambilnya (Kasmir 2013). Dalam hal ini salah satu syarat kredibilitas debitur adalah jaminan yang harus disediakan sebagai pertanggungjawaban bila debitur tidak dapat melunasi utangnya (Asikin 2016).

Suatu prinsip yang berlaku dalam hukum jaminan adalah kreditur tidak dapat meminta suatu janji agar benda yang dijaminkan bagi pelunasan utang 
debitur diberikan kepada kreditur. Logika dari ketentuan ini adalah untuk mencegah terjadinya ketidakadilan yang akan terjadi jika kreditur memiliki benda jaminan yang nilainya lebih besar dari jumlah utang debitur kepada kreditur. Karena itu benda jaminan tersebut harus dijual dan kreditur berhak mengambil uang hasil penjualan tersebut sebagai pelunasan piutangnya. Apabila masih ada kelebihan, maka sisa hasil penjualan tersebut harus dikembalikan kepada debitur (Suharnoko 2008).

Suatu transaksi telah sesuai dengan prinsip syariah apabila telah memenuhi beberapa syarat, yaitu transaksi tidak mengandung unsur kezaliman, bukan riba, tidak membahayakan pihak sendiri atau pihak lain, tidak ada penipuan (gharar), tidak mengandung materi-materi yang diharamkan, dan tidak mengandung unsur judi (maysir) (Muhamad 2015). Perjanjian harus senantiasa mendatangkan keuntungan yang adil dan seimbang, serta tidak boleh mendatangkan kerugian bagi salah satu pihak (Umam 2016). Artinya, transaksi yang menimbulkan ketidakadilan bagi pihak lainnya adalah mengandung unsur zalim (Mardani 2015). Oleh karena itu, setiap kontrak yang dilakukan oleh pihak-pihak yang berkepentingan, maka prinsip keadilan sangat menentukan berlangsungnya kontrak tersebut, sebab keadilan itu merupakan hal bersifat multidimensional yang berintikan kebenaran (Manan 2012).

Dalam membahas cessie sebagai jaminan utang, jika dibandingkan dengan fidusia, debitur menyerahkan hak miliknya secara kepercayaan kepada kreditur, sedangkan pada cessie tanpa secara terang-terangan disebutkan bahwa penyerahannya adalah secara kepercayaan (Supramono 2009).

Cessie dapat dijadikan sebagai jaminan utang yang di dalamnya mengandung syarat batal. Maksudnya, dalam hal cessie sebagai jaminan utang, harus dinyatakan bahwa cessie akan berakhir dengan pelunasan utang debitur (Purnamasari 2012). Kontrak bersyarat adalah kontrak yang digantungkan pada suatu peristiwa yang akan datang dan peristiwa tersebut belum tentu akan terjadi. Kontrak bersyarat ini dapat dibagi dua, yaitu kontrak dengan syarat tangguh dan 
kontrak dengan syarat batal. Suatu kontrak disebut kontrak dengan syarat tangguh jika untuk lahirnya kontrak tersebut digantungkan pada suatu peristiwa tertentu yang akan datang dan belum tentu akan terjadi, sedangkan suatu kontrak disebut kontrak dengan syarat batal jika untuk batalnya atau berakhirnya kontrak tersebut digantungkan pada suatu peristiwa yang akan datang dan belum tentu akan terjadi (Miru 2012).

Cessie sebagai penyerahan piutang atas nama artinya hak milik atas piutang kreditur lama (cedent) sudah beralih kepada kreditur baru (cessionaris). Tetapi pada cessie piutang atas nama sebagai jaminan tidak ada pengalihan penguasaan dari barang, dimana barang tersebut tetap berada pada kreditur lama (cedent). Karena secara yuridis pada dasarnya apabila kreditur lama tidak memenuhi kewajibannya, maka tidak diperkenankan kreditur baru memiliki barang yang diagunkan. Dalam hal ini, perjanjian pengalihan piutang merupakan perjanjian ikutan (accessoir) terhadap perjanjian kredit. Dalam hal piutang sebagai jaminan kredit, cessionaris menguasai piutang seolah-olah piutang tersebut miliknya atau cessionaris sebagai bezitter, namun piutang-piutang yang dialihkan oleh cedent kepada cessionaris tersebut pengurusannya tetap berada pada cedent (constitutum possesorium) (Wangsawidjaja 2012).

Di dalam hukum Islam, hawalah secara bahasa terkadang diartikan shahadah (kesaksian) dan kafalah (jaminan) (Hakim 2011). Menurut metodologi ushul figh, hawalah dapat dianalogikan dengan kafalah (jaminan) (Muhammad 2000). Hawalah dalam arti kafalah merupakan perjanjian untuk menjamin, oleh karena itu suatu jaminan tidak ada apabila hak-hak yang dijamin tidak ada. Akad tersebut termasuk dalam kategori akad accessoir (al-'aqd at-tab'i), yaitu akad yang keberadaannya tidak berdiri sendiri, melainkan tergantung kepada suatu hak yang menjadi dasar ada dan tidaknya atau sah dan tidak sahnya akad tersebut. Terhadap akad jenis ini berlaku kaidah hukum Islam yang berbunyi "suatu yang mengikut mengikut" (at-tabi' tabi'). Artinya perjanjian accessoir ini yang mengikut 
kepada perjanjian pokok, hukumnya mengikuti perjanjian pokok tersebut (Anwar 2010).

Pada penyerahan jaminan suatu piutang atas nama, suatu perjanjian tertulis (schriftelijk stuk) merupakan syarat keabsahannya. Bilamana penyerahan piutang itu dilakukan, maka debitur harus diberitahu dan pemberitahuan ini dilakukan dengan upaya suatu deurwaardersexploit. Pemberitahuan formal ini hanya dapat digantikan dengan suatu penerimaan secara tertulis atau pengakuan akan penyerahan itu oleh debitur (Prawirohamidjojo and Pohan 1991). Salah satu prinsip dasar dalam pembuatan akad di dalam hukum Islam adalah dibuat atas dasar ridha kedua belah pihak. Selain itu, penulisan haruslah diperhatikan, pentingnya dokumen yang ditandatangani dan disaksikan oleh para pihak yang melakukan perjanjian. Penulisan ini dimungkinkan terkait dengan variabel jangka waktu dalam suatu jenis transaksi (Anshori 2011).

Bilamana piutang yang dipindahkan sebagai jaminan itu menjadi gugur (misalnya karena pelunasan), maka retro cessie harus dilakukan (Prawirohamidjojo and Pohan 1991). Retro cessie adalah pengembalian cessie dari cessionaris kepada cedent dikarenakan piutang yang dimaksud sudah tidak dapat ditagih lagi. Retro cessie memang diperlukan untuk menjamin kepentingan cessionaris. Namun hal ini harus dijanjikan oleh cedent dan cessionaris dalam akta cessie atau dijanjikan dalam perjanjian yang mendasari cessie, karena retro cessie bukan merupakan hak yang diberikan oleh undang-undang (Suharnoko et al. 2005). Terkait dengan retro cessie di dalam hukum Islam, para ulama Hanafi mensyaratkan bolehnya pihak ketiga (cessionaris) untuk menagih kembali (recourse) kepada muhal (cedent), dengan dasar hawalah haqq yang didasarkan pada kafalah (penjaminan) oleh muhal (cedent). Sedangkan ulama Syafi'i tidak membolehkannya karena sudah ada persetujuan di antara ketiga pihak (Hakim 2012). 


\section{SIMPULAN}

Syarat-syarat cessie menurut KUH Perdata belum memenuhi keseluruhan syarat pembentukan akad di dalam hukum Islam yang terkandung di dalam hawalah, yaitu obyek akad cakupannya sangat luas serta belum tentu sesuai dengan ketentuan syara' yang harus terbebas dari unsur larangan, yakni riba, maysir, dan gharar. Karena menurut KUH Perdata, selama kesepakatan telah memenuhi syarat-syarat sah perjanjian, maka kesepakatan tersebut adalah sah dan merupakan undang-undang bagi para pihak yang membuatnya.

Cessie dalam jual beli piutang termasuk di dalam hawalah haqq karena keduanya adalah akad pengalihan piutang yang dapat terjadi karena pertukaran/jual beli. Terdapat dua pendapat para ulama, yakni tidak membolehkan dan membolehkannya dengan beberapa syarat tertentu. Dalam hal harga penjualan piutang, sebagian ulama berpendapat bahwa piutang boleh dijual sesuai dengan harga pasar (termasuk dengan harga diskon), sedangkan ulama yang lain berpendapat bahwa piutang hanya boleh dijual dengan piutang yang senilai. Cessie sebagai jaminan utang termasuk dalam hawalah haqq yang didasarkan pada kafalah (penjaminan) karena keduanya adalah akad pengalihan piutang sebagai jaminan. Dalam hal retro cessie, terdapat perbedaan pendapat ulama, ulama Hanafi membolehkan sedangkan ulama Syafi'i tidak membolehkan.

\section{DAFTAR PUSTAKA}

Anshori, Abdul Ghofur. 2011. Gadai Syariah Di Indonesia: Konsep, Implementasi, Dan Institusionalisasi. Yogyakarta: Gadjah Mada University Press.

Anwar, Syamsul. 2010. Hukum Perjanjian Syariah. 1st ed. Jakarta: Rajawali Pers.

Arifin, Zainul. 2003. Dasar-Dasar Manajemen Bank Syariah. Jakarta: AlvaBet.

Asikin, Zainal. 2016. Pengantar Hukum Perbankan Indonesia. Jakarta: Rajawali Pers. 
Djamil, Fathurrahman. 2012. Penerapan Hukum Perjanjian Dalam Transaksi Di Lembaga Keuangan Syariah. Jakarta: Sinar Grafika.

Fuady, Munir. 2014. Konsep Hukum Perdata. 1st ed. Jakarta: Rajawali Pers.

Hakim, Atang Abd. 2011. Figh Perbankan Syariah: Transformasi Fiqih Muamalah Ke Dalam Peraturan Perundang-Undangan. Bandung: PT Refika Aditama.

Hakim, Cecep Maskanul. 2012. Belajar Mudah Ekonomi Islam: Catatan Kritis Terhadap Dinamika Perkembangan Perbankan Syariah Di Indonesia. Tangerang: Shuhuf Media Insani.

Hariri, Wawan Muhwan. 2011. Hukum Perikatan: Dilengkapi Hukum Perikatan Dalam Islam. Bandung: CV Pustaka Setia.

HS., Salim. 2005. Pengantar Hukum Perdata Tertulis (BW). Jakarta: Sinar Grafika.

- - . 2016. Perkembangan Hukum Jaminan Di Indonesia. Jakarta: Rajawali Pers.

Huda, Nurul, and Mohamad Heykal. 2010. Lembaga Keuangan Islam: Tinjauan Teoritis Dan Praktis. 1st ed. Jakarta: Kencana.

Karim, Adiwarman. 2004. Bank Islam: Analisis Fiqih Dan Keuangan. 2nd ed. Jakarta: PT Raja Grafindo Persada.

Kasmir. 2013. Dasar-Dasar Perbankan. Jakarta: Rajawali Pers.

Manan, Abdul. 2012. Hukum Ekonomi Syariah: Dalam Perspektif Kewenangan Peradilan Agama. Jakarta: Kencana.

Mardani. 2010. Hukum Islam: Pengantar IImu Hukum Islam Di Indonesia. Yogyakarta: Pustaka Pelajar.

- - . 2015. Aspek Hukum Lembaga Keuangan Syariah Di Indonesia. Jakarta: Kencana.

Miru, Ahmadi. 2012. Hukum Kontrak Bernuansa Islam. 1st ed. Jakarta: Rajawali 
Pers.

- - . 2016. Hukum Kontrak \& Perancangan Kontrak. Jakarta: Rajawali Pers.

Muhamad. 2015. Manajemen Dana Bank Syariah. Jakarta: Rajawali Pers.

Muhammad. 2000. Sistem Dan Prosedur Operasional Bank Syariah. Yogyakarta: UII Press.

Natadimaja, Harumiati. 2009. Hukum Perdata: Mengenai Hukum Perorangan Dan Hukum Benda. 1st ed. Yogyakarta: Graha IImu.

Nawawi, Ismail. 2012. Fikih Muamalah Klasik Dan Kontemporer: Hukum Perjanjian, Ekonomi, Bisnis, Dan Sosial. Bogor: Ghalia Indonesia.

PPHIMM, Pusat Pengkajian Hukum Islam dan Masyarakat Madani. 2009. Kompilasi Hukum Ekonomi Syariah. Jakarta: Kencana.

Prakoso, Djoko. 1989. Hukum Asuransi Indonesia. Jakarta: Bina Aksara.

Prawirohamidjojo, R. Soetojo, and Marthalena Pohan. 1991. Bab-Bab Tentang Hukum Benda. Surabaya: PT Bina Ilmu.

Prodjodikoro, R. Wirjono. 2000. Azas-Azas Hukum Perjanjian. Bandung: Mandar Maju.

Purnamasari, Irma Devita. 2012. Panduan Lengkap Hukum Praktis Populer: KiatKiat Cerdas, Mudah, Dan Bijak Memahami Masalah Hukum Jaminan Perbankan. Bandung: Kaifa.

Rahman, Sufirman, and Eddie Rinaldy. 2013. Hukum Surat Berharga Pasar Uang. Jakarta: Sinar Grafika.

Sahrani, Sohari, and Ru'fah Abdullah. 2011. Fikih Muamalah. Bogor: Ghalia Indonesia.

Sakkirang, Sriwaty. 2011. Hukum Perdata. Yogyakarta: Teras. 
Saliman, Abdul Rasyid, and Et.al. 2008. Hukum Bisnis Untuk Perusahaan: Teori Dan Contoh Kasus. 2nd ed. Jakarta: Kencana.

Sofwan, Sri Soedewi Masjchoen. 1981. Hukum Perdata: Hukum Benda. Yogyakarta: Liberty.

Subekti, R. 2000. Perbandingan Hukum Perdata. Jakarta: Pradnya Paramita.

Sugiarto, Umar Said. 2013. Pengantar Hukum Indonesia. Jakarta: Sinar Grafika.

Suhardana, FX. 2009. Contract Drafting: Kerangka Dasar Dan Teknik Penyusunan Kontrak. Yogyakarta: Universitas Atma Jaya Yogyakarta.

Suharnoko. 2008. Hukum Perjanjian: Teori Dan Analisa Kasus. Jakarta: Kencana.

Suharnoko, and Et.al. 2005. Doktrin Subrogasi, Novasi, Dan Cessie. 1st ed. Jakarta: Kencana.

Supramono, Gatot. 2009. Perbankan Dan Masalah Kredit: Suatu Tinjauan Di Bidang Yuridis. Jakarta: Rineka Cipta.

Sutarno. 2014. Aspek-Aspek Hukum Perkreditan Pada Bank. Bandung: Alfabeta.

Sutedi, Adrian. 2009. Aspek Hukum Obligasi Dan Sukuk. 1st ed. Jakarta: Sinar Grafika.

TLP, Tim Laskar Pelangi. 2013. Metodologi Fiqih Muamalah: Diskursus Metodologis Konsep Interaksi Sosial-Ekonomi. Kediri: Lirboyo Press.

Umam, Khotibul. 2016. Perbankan Syariah: Dasar-Dasar Dan Dinamika Perkembangannya Di Indonesia. Jakarta: Rajawali Pers.

Usman, Rachmadi. 2009. Hukum Jaminan Keperdataan. 1st ed. Jakarta: Sinar Grafika.

Wangsawidjaja, A. 2012. Pembiayaan Bank Syariah. Jakarta: PT Gramedia Pustaka Utama. 
Widjaja, Gunawan, and E. Paramitha Sapardan. 2006. Seri Aspek Hukum Dalam Pasar Modal: Asset Securitization (Pelaksanaan SMF Di Indonesia). Jakarta: PT Raja Grafindo Persada.

Winarno, Sigit, and Sujana Ismaya. 2006. Kamus Perbankan. Bandung: Pustaka Grafika. 